Journal of Science Education Research

Journal homepage: www.journal.uny.ac.id/jser

JSER

\title{
Science Process Skills and Its Implementation in the Process of Science Learning Evaluation in Schools.
}

\author{
Atik Kurniawati ${ }^{*}$ \\ ${ }^{1}$ Study Program of Biology Education, Faculty of Mathematics and Natural Sciences, Universitas Negeri Yogyakarta \\ Corresponding Author. Email: atik_kurniawati@uny.ac.id
}

Keywords:

Process skills, learning evaluation, science

\begin{abstract}
The study aimed to find out the science process skills and its implementation in the process of science learning evaluation in the schools. The studied aspects in the study consisted of the nature of science process skills, types of science process skills, assessment techniques for science process skills, and the assessment implementation of science process skills in learning in the schools. The research used a literature study containing relevant theories and further elaborated and its implementation in science learning in the schools. The study emphasized that science process skills were closely related to science learning and prioritize the overall assessment following the nature of science, such as product, process, and attitude dimensions. Those were covered in basic and integrated process skills. The most possible evaluation technique in measuring the science process skills was by observation or performance and written questions following the indicators of science process skills.
\end{abstract}

\section{INTRODUCTION}

Today, one of the important goals of education is teaching the skills of both scientific thinking and science process to students. In recent years, many countries have emphasized scientific thinking and science process skills in science learning curricula, starting from primary school to university. Science process skills that are taught in science subjects are very important to every student as it is the first step to stimulate students to use thinking and creativity effectively (Houtz, 2010). Therefore, the teacher, especially the science teacher needs to teach and evaluate the students' science process skills.

Science process skills are taught when students perform scientific inquiries, so the learning evaluation must be also integrated with these skills. Science process skills are grouped into two, namely: basic and integrated skills which include observing, measuring, classifying, asking, formulating hypotheses, planning an experiment, identifying variables, determining work steps, experimenting, creating and interpreting information/graphics, applying concepts, concluding, and communication both verbal and nonverbal (Sheeba, 2013).
Teachers in teaching science with an approach of science process skills must also emphasize using integrated science process skills during an evaluation. The integrated may define as a coin that the two sides are inseparable. These skills are divided into three main components, namely scientific attitudes, scientific processes, and scientific products (Putra \& Suana, 2015). Process skills or scientific methods are part of the study of science. This section will briefly review related to the nature of science process skills, types of science process skills, assessment techniques for science process skills, and the implementation of science assessment for Science Process Skills.

\section{METHOD}

The research used a literature study containing relevant theories and further elaborated and its implementation in science learning in the schools. The research also assesses the concepts and literature, especially from published articles in scientific journals. The literature study was chosen with the aim to build a concept or theory that plays as the basis of studies in research (Sujarweni, 2014). 


\section{RESULT}

\section{The Nature of Science Process Skill}

In science, science process skill is a building of critical thinking and inquiry that is obtained through science learning activities (Sheeba, 2013). Process skills refer to cognitive processes or thinking processes where students are directly involved in learning science. The science process skills taught by teachers produce a product of science learning, including meanings, definitions, explanations of terms, concepts, principles, laws, theories, and so on, that relate to the domain of science. The term science process skills were popularized through the Science-A Process Approach (SAPA) curriculum project. And, Science Process Skills may define as a set of transferable skills and describe the habits of a researcher (Houtz, 2010).

Science process skills are a reflection of the methods used by scientists in producing comprehensive information about science such as product, attitude, process, and application dimensions (Setyawarno et al., 2020). The products of science learning are produced through the application of process skills in learning either classroom or laboratory. Process skills that are more often used and emphasized by students in studying science and scientists in problem-solving are called process skills in science. Components of scientific attitudes are grown in process skill-science based learning, including responsibility, curiosity, honesty, openness, objective, creativity, tolerance, work accuracy, self-confidence, and so on, related to scientific attitudes. The component that is taught in learning is the scientific method in experimenting or investigating as scientists in the field of science.
Moreover, Pratt \& Hackett stated that "science process skills are based on scientific inquiry and teaching science by inquiry involves teaching students science process skills, critical thinking, scientific reasoning skills used by scientists" (Pratt \& Hackett, 1998). These skills are the skills that facilitate science learning, ensure student participation, require students to develop a sense of responsibility, improve the quality of learning, and require students to acquire research methods. And, they ensure to think and have an attitude like a scientist. Science learning is not just a mastery of concepts but also leads to the discovery process (Radinsky, 2016). The explanation showed that science does not only consist of memorizing the facts, concepts, and theories but also including activities or processes using scientific thoughts and attitudes in studying natural phenomena. Generally, science is divided into three components, namely (1) scientific attitudes, (2) scientific processes, and (3) scientific products.

\section{Types of Science Process Skills}

Science process skills are grouped into two, namely: basic and integrated skills (Sheeba, 2013; Sermsirikarnjana et al., 2017). Basic process skills consist of observing, inferring, measuring, communicating, classifying, predicting, and using space-time integrated and numbers. Integrated process skills consist of controlling variables, defining operationally, formulating hypotheses, formulating models, interpreting data, and experimenting. These two skills are briefly presented in Figure 1.

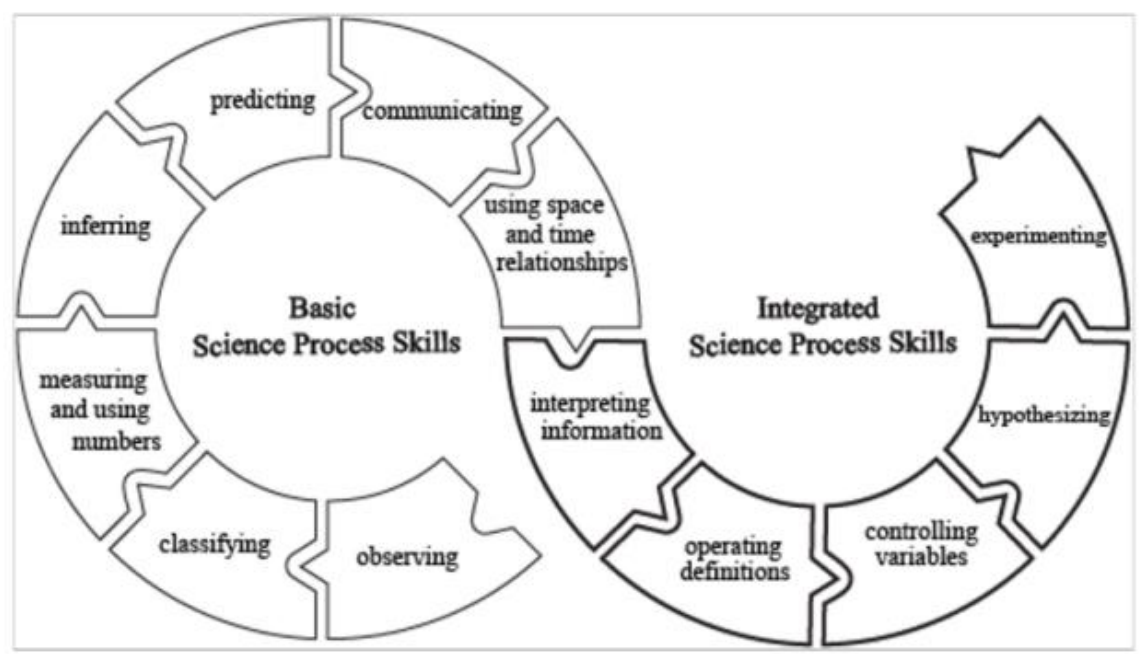

Figure 1. Basic and integrated science process skills 
Science Process Skills (SPS) are very useful in designing and constructing scientific facts in natural sciences at the school level and scientific activities which involve a variety of methods, including such activities as observing phenomena, questioning, scrutinizing, examining books, and also other sources of information to find out about the phenomenon (Baharom, 2020). Science-A Process Approach SAPA classifies science process skills into two groups; first, Basic Science Process Skills consists of observing, inferring, measuring, communicating, classifying, and predicting. Second, integrated science process skills consist of controlling variables, defining operationally, formulating hypotheses, interpreting data, experimenting, and formulating models (Sheeba, 2013; Sermsirikarnjana et al., 2017). The following is an explanation of each science process skill.

\section{Observation}

Observations are not just seeing or use the sense of sight, but involve the abilities of our five senses, namely the senses of sight, hearing, taste, touch, and smell. Some activities that occur during observation are:

a. Use the five senses, not only the sense of sight;

b. Organizing objects according to certain characteristics;

c. Identifying;

d. Identifying the changes of an object;

e. Conduct a quantitative observation

f. Conduct a qualitative observation.

Observations must be free of assumptions and opinions. Observations must honestly report what is received or captured by the five senses. Observations that only use the senses without referring to certain standard units of measurement are called qualitative observations. Meanwhile, observations that use measuring instruments and refer to certain standard units of measurement are called quantitative observations. Quantities obtained from counting include quantitative observations. Observations that only use one sense might not provide a complete description of the object being observed. Carin suggests seven components to good scientific observation (Carin, 1993). They are:

a. Plan. The purpose of planning is to minimize missing the important things or avoid unnecessary repetition.

b. Sense. Use all five senses and be free from the opinions and assumptions of observers.

c. Question. Critical and asking questions aim to obtain more information on the object of observation.

d. Measurement. Measurements are carried out with measuring instruments and standard units. e. Similarities and Differences. Observations of these two things are used to group or classify aiming to see a pattern of regularity.

f. Changes. Pay close attention to the changes.

g. Communications. Occur both writing and oral using descriptions, diagrams, pictures, and other appropriate methods.

2. Use of numbers

The use of numbers includes sorting, counting, adding, subtracting, multiplying, and dividing.

\section{Classification}

Classification is the grouping of objects according to a certain characteristic. Classification may be through following ways:

a. identification of a common trait,

b. sorting by using two or more characteristics based on the similarities and differences.

\section{Measurement}

Measurement is an activity to compare with a unit of measurement and use in quantitative observations. Measurement activities may be through the following form:

a. measurement of length, volume, mass, temperature, and time in appropriate units;

b. select the appropriate tools and units for the particular measurement task.

5. Communication

Use to expose or write data as clearly as possible. Communication may be through following ways:

a. Presentation the result of the observation;

b. Use graphs or pictures to present the result of observations and data demonstrations;

c. Create posters or diagrams to present the data to others.

6. Predicting

Predicting is exposing the possible results from an experiment based on observations and previous inferences about what observations may be encountered in the future. While inference seeks to provide reasons for why an observation occurs. The prediction may occur in the following ways:

a. Use appropriate data and observations;

b. Interpretation the generalizations of patterns;

c. Test the truth of the appropriate predictions.

7. Inferential

Inferential is used for an observed object to explain the occurred phenomena, such as:

a. Associate observations with previous experience or knowledge;

b. Propose explanations for observations.

8. Identification and Control of Variables

In scientific research, there are 3 (three) kinds of important variables, namely manipulating variables, response variables, and controlling 
variables. Some activities in controlling variables are:

a. Identify variables that affect the results;

b. Identify the changed variables in the experiment;

c. Identify the controlled variables in an experiment.

\section{Data Interpretation}

Data interpretation is an activity to explain the meaning of the collected information. Data interpretation may be performed through the ways:

a. Data compiling;

b. Recognize the patterns or relationships;

c. Formulate appropriate inferences using data;

d. Summary the data correctly.

10. Hypothesis Formulation

A hypothesis is a reasonable and testable conjecture about how or why something happened or occurred. Formulating a hypothesis may be through the following ways:

a. formulation of hypotheses based on observation and inference,

b. designing ways to test hypotheses,

c. revise the hypothesis when the data do not support the hypothesis.

11. Operational Definition of Variables

The operational definition of variables is an activity to define based on what they do or what they observe. Steps in the operational definition of variables are;

a. Describe experiences using concrete objects,

b. Expose what the objects do,

c. Describe changes or measurements during an experiment.

12. Experiments

Experiments are activities of testing hypotheses or predictions. Experiments may define as a planned systematic effort to produce data to answer a problem formulation or test a hypothesis. The experiment may be performed through the following activities:

a. formulating and testing predictions about phenomena,

b. propose and test hypotheses,

c. identify and control the variables,

d. evaluate predictions and hypotheses following the experimental results.

\section{Assessment Techniques for Science Process Skills}

Assessment always involves to learning, including assessment for science process skills (Rosana, 2015). Science process skills describe the students' ability to apply scientific methods in understanding, developing, and discovering knowledge. For students, Science Process Skills are important to understand as a step to use the scientific method in developing science. And, through this skill, they hope to acquire new knowledge or develop the knowledge. Skills may define as the ability to use thoughts, reason, and actions efficiently and effectively to achieve a certain result, including creativity.

The process may define as a complex set of skills that scientists use in conducting scientific research. The process is a journey to discover the major concepts that could be divided into components to achieve an activity goal. Assessment outside the aspect of knowledge should occur more objectively. However, the assessment can eliminate the element of fair for students if it does not complete with clear assessment criteria (Centre for Teaching and Learning, 2017).

Characteristics of science process skills related to the learning assessment process in the classroom are explained as follow:

\section{General characteristics}

The assessment is not included the concepts, aiming the measurement could well measure the concept mastery among students. The measurement contains some information, such as pictures, diagrams, graphs, data in tables or descriptions, and the original object. The measured aspect is clear and containing only one aspect, for example, interpretation.

\section{Specific characteristics}

Observation of the actual object or phenomena. Interpretation presents some data to show regularity/classification patterns, providing an opportunity to finding similarities and differences, given certain criteria for grouping, or determining the number of groups that they should make. Predicting is a clear pattern or tendency to make predictions. Communication is a particular form of presentation that changed to another form of presentation. Hypotheses formulate conjectures, prediction or temporary answers, or test statements containing a relationship between two or more variables. Planning an experiment or investigation provides an opportunity to propose ideas relating to the tools/materials, the step of procedures, determining variables, and controlling variables. Apply a concept or principle without naming the concept. Ask questions with surprising, impossible, unusual, or contractual questions to motivate students to ask questions.

The assessment preparation of the science process skills should choose one particular concept. Then, it presents some information that must be answered by students. After that, determine the form of the answer, for example, across, a check-mark, or write three short answers and then prepare questions to get the expected answer. Assessment of process skills requires scoring in a certain way. Each correct response is scored with a certain score, for example, 1 for a minimal score assessment of observations. For more complex responses, for example, making 
questions and give a varied score based on the level of difficulty (Setyawarno, 2020). For example, a question with a hypothetical background is given a score of 3; the questions of what, why, and how are given a score of 2; a Question that asks for an explanation is given a score of 1 .

\section{Implementation of Science Process Skill Assessment in science learning}

Assessment of science process skills in science learning may be through various ways following the learning. The implementation itself is closely related to the assessment technique. The implementation of the assessment of science process skills, namely:

1. Observation or performance

It may conduct in every meeting, both in the classroom, laboratory, and field, by using an observation format.

\section{Written-test}

It may use objective tests and descriptions. Students may require to state the reasons for their answer, which aim to know whether the student guessed or knew in answering. The teacher must also have the assessment rubric during the assessment. The rubric is an assessment guide to describe the criteria used by teachers in assessing or scoring the student work (Centre for Teaching and Learning, 2017). The rubric should include a list of the characteristics in a student's work and be completed by a guide for evaluating the characteristics. The assessment can eliminate the element of fair for students if it does not complete with clear assessment criteria (Centre for Teaching and Learning, 2017). Scoring use to assess the work (product or process), regardless of its component parts.

\section{CONCLUSION}

Science process skills were closely related to science learning and prioritize the overall assessment following the nature of science, such as product, process, and attitude dimensions. Those were covered in basic and integrated process skills. The most possible evaluation technique in measuring the science process skills was by observation or performance and written questions following the indicators of science process skills.

\section{REFERENCES}

Baharom, M. M. (2020). Integration of Science learning Apps based on Inquiry Based Science Education (IBSE) in enhancing Students Science Process Skills (SPS). International Journal of Interactive Mobile Technologies (IJIM), 14(9), 95-109. https://doi.org/10.3991/ijim.v14i09.11706

Carin, A. A. (1993). Teaching Science through Discovery. Macmillan Publishing Company.

Centre for Teaching and Learning. (2017). Introduction to Teaching and Learning. Aarhus University.

Houtz, B. (2010). Teaching science today. Corinne Burton.

Pratt, H., \& Hackett, J. (1998). Teaching Science: The Inquiry Approach. Principal, 78(2), 2 20.

Putra, N. A. R., \& Suana, W. (2015). Pengaruh keterampilan proses sains dan sikap ilmiah terhadap pemahaman konsep ipa. Jurnal Pembelajaran Fisika, 3(4), 10.

Radinsky, J. (2016). Constructions of the self as learner: Perspective-Taking and Positioning in Matthematics, History, and scence Learning. Journal of the Learning Science, 25(3), 331-334. https://doi.org/10.1080/10508406.2016.120 3621

Rosana, D. (2015). Evaluasi pembelajaran sains (1st ed., Vol. 1). UNY Press.

Sermsirikarnjana, P., Kiddee, K., \& Pupat, P. (2017). An integrated science process skills needs assessment analysis for Thai vocational students and teachers. AsiaPacific Forum on Science Learning and Teaching, 18(2), 25.

Setyawarno, D. (2020). Analisis skor. FMIPA Universitas Negeri Yogyakarta.

Setyawarno, D., Widodo, E., \& Setyaningsih, W. (2020). Asesmen pembelajaran sains. UNY Press.

Sheeba, M. N. (2013). An Anatomy of Science Process Skills In The Light Of The Challenges to Realize Science Instruction Leading To Global Excellence in Education. Educationia Confab.

Sujarweni, W. (2014). Metodologi penelitian. Pustaka Baru Press. 